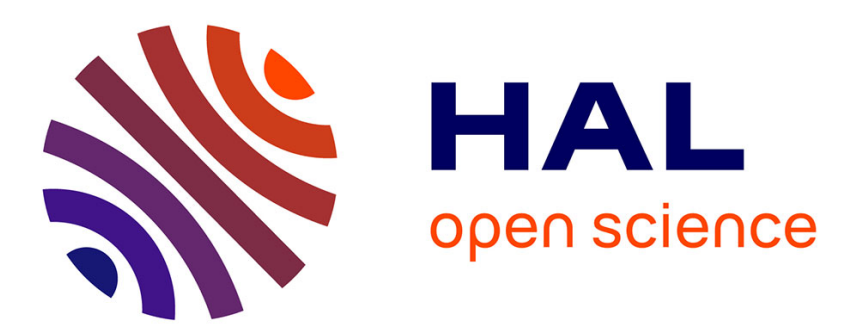

\title{
Origin of powdery mildew resistance factors in RE714, a wheat breeding line obtained from two interspecific crosses
}

\author{
H. Muranty, M.T. Pavoine, G. Doussinault, Dominique D. Barloy
}

\section{- To cite this version:}

H. Muranty, M.T. Pavoine, G. Doussinault, Dominique D. Barloy. Origin of powdery mildew resistance factors in RE714, a wheat breeding line obtained from two interspecific crosses. Plant Breeding, 2010, 129 (5), pp.465-471. 10.1111/j.1439-0523.2009.01740.x . hal-00729590

HAL Id: hal-00729590

https://institut-agro-rennes-angers.hal.science/hal-00729590

Submitted on 31 May 2020

HAL is a multi-disciplinary open access archive for the deposit and dissemination of scientific research documents, whether they are published or not. The documents may come from teaching and research institutions in France or abroad, or from public or private research centers.
L'archive ouverte pluridisciplinaire HAL, est destinée au dépôt et à la diffusion de documents scientifiques de niveau recherche, publiés ou non, émanant des établissements d'enseignement et de recherche français ou étrangers, des laboratoires publics ou privés. 
Version définitive du manuscrit publié dans / Final version of the manuscript published in :

Plant breeding, 2010, 129 (5), 465-471 http://dx.doi.org/10.1111/j.1439-0523.2009.01740.x

\title{
Origin of powdery mildew genetic resistance factors in RE714, a wheat breeding line obtained from two interspecific crosses
}

\section{H. Muranty ${ }^{1,2}$, M.-T. Pavoine ${ }^{1}$, G. Doussinault ${ }^{1}$, D. Barloy ${ }^{1}$}

${ }^{1}$ INRA Agrocampus Rennes UMR118 Amélioration des Plantes et Biotechnologies Végétales, BP 35327, 35653 LE RHEU CEDEX, FRANCE

${ }^{2}$ Present address : INRA UR 0588 Amélioration Génétique et Physiologie Forestières, 2163 avenue de la Pomme de Pin - CS40001 - Ardon, 45075 ORLEANS CEDEX 2, FRANCE. Helene.Muranty@orleans.inra.fr, phone: 332384178 47, fax : 33238417879

With 2 figures and 3 tables

Received July 10, 2009/ Accepted October 24, 2009

Communicated by R.A. McIntosh

\begin{abstract}
RE714 is a winter wheat breeding line obtained from two interspecific crosses [(Aegilops tauschii no. 33/Triticum dicoccum no. 119) and VPM $=$ (Aegilops ventricosa no.10/T. persicum)//Marne]. RE714 expresses powdery mildew resistance at the seedling, vernalized and adult stages. The origin of the main genetic factors involved in RE714 powdery mildew resistance (Pm4b, QPm.inra-5D, QPm.inra-6A2, QPm.inra-7A3a and QPm.inra-7A3b) was studied by comparing alleles of RE714 and those of seven of its parental lines with 36 microsatellite markers previously detected as linked to these factors. VPM, and among its parental lines, the T. persicum accession, were identified as the donor of Pm4b to RE714. Aegilops tauschii $\mathrm{n}^{\circ} 33$ and T. dicoccum $\mathrm{n}^{\circ} 119$ were identified as the donors of QPm.inra-5D and QPm.inra-6A2 to RE714, respectively. Beauchamp, a line used at the end of the breeding scheme that created RE714, might be the donor of the favourable alleles of RE714 at quantitative trait loci on linkage group 7A3. These results are discussed in the context of introgression of valuable genetic factors from related species of the primary gene pool into wheat.
\end{abstract}

Key words: wheat - introgression - powdery mildew - resistance genes 
Version définitive du manuscrit publié dans / Final version of the manuscript published in :

Plant breeding, 2010, 129 (5), 465-471 http://dx.doi.org/10.1111/j.1439-0523.2009.01740.x

Domestication and modern intensive plant breeding are generally considered to be practices that lead to reduced genetic diversity in crop cultivars. For example, Roussel et al. (2004) showed a decrease in allelic richness of about $25 \%$ between landraces cultivated between 1800 and 1840 and varieties cultivated after 1840 for common wheat (Triticum aestivum L) in France. Wild relatives and related species of crop plants represent the best hope for continuous crop genetic improvement because they harbour desirable agronomic traits such as biotic and abiotic stress resistances and special quality traits (Xie and Nevo 2008). Awareness of this fact led to the building of several conservation programmes of plant genetic resources, either ex situ or in situ. Although conservation of biodiversity is still needed, the next challenge is to develop innovative breeding strategies to incorporate favourable alleles, genes or gene complexes from genetic resources into cultivated genotypes (Feuillet et al. 2008) without introducing too much associated wild genetic material with unacceptable wild traits. Associated unfavourable genetic material is often referred to as linkage drag. Genetic recombination during meiosis followed by selection can be used to reduce linkage drag. For about 10 years, breeders have introduced molecular markers in the selection step to tag the favourable allele(s) and to estimate the length of the associated introduced segment(s) and reduce it in marker-assisted backcross or genotype building schemes (Hospital 2005).

The most cultivated wheat species today are bread wheat (Triticum aestivum) and pasta wheat (T. durum), which are hexaploid (AABBDD) and tetraploid (AABB), respectively. The wild relatives of wheat can be classified on the basis of their genomic constitutions into primary, secondary and tertiary gene pools (Jiang et al. 1994). The primary gene pool includes landraces, early domesticates and wild relatives that hybridize directly with the cultivated types. Their genomes are homologous to the AA (T. monococcum, including var. beoticum and var. urartu) or the DD (Aegilops tauschii) or the AABB genomes (T. turgidum, $T$. dicoccum and $T$. dicoccoides) of cultivated wheats. The secondary gene pool contains polyploid species that share at least one homologous genome with the cultivated types. The tertiary gene pool contains species that do not share a homologous genome with the cultivated types. Gene transfer from these species can only be achieved by sophisticated strategies generally referred to as "chromosome engineering" (Qi et al. 2007).

The winter wheat breeding line RE714 was developed from an interspecific cross (Aegilops tauschii no. 33/Triticum dicoccum no. 119) which was crossed to several lines including lines derived from VPM/Moisson (VPM = Aegilops ventricosa no.10/T. persicum//3* Marne) in a breeding program for disease resistance at INRA, Rennes (France) (Trottet and Dosba 1983; Robe and Doussinault 1995); (Fig. 1). These crosses involved species from the primary gene 
Version définitive du manuscrit publié dans / Final version of the manuscript published in :

Plant breeding, 2010, 129 (5), 465-471 http://dx.doi.org/10.1111/j.1439-0523.2009.01740.x

pool of cultivated bread wheat, namely Ae. tauschii, with the $\mathrm{D}$ genome, and T. dicoccum and $T$. persicum ( $=T$. carthlicum), with the A and B genomes, and a species from the secondary gene pool, namely Ae. ventricosa, with the $\mathrm{D}$ and $\mathrm{N}^{\mathrm{v}}$ genomes. G. Doussinault sent seeds of RE714 to several breeders in France and Europe, but few reported if they used it: we only know that it was used in Switzerland (D. Fossati pers. comm.). RE714 expresses powdery mildew resistance at the seedling, vernalized and adult stage and the genetic basis of its resistance has been studied in detail (Robe and Doussinault 1995, Chantret et al. 1999, 2000, 2001, Mingeot et al. 2002, Muranty et al. 2008, 2009). Three main genetic factors control RE714 powdery mildew resistance at the seedling stage. These are $P m 4 b$, located on chromosome 2A, QPms.inra-5D located on chromosome 5D and QPms.inra-6A2 located on chromosome 6A (Muranty et al. 2008). Two major quantitative trait loci (QTL), QPm.inra$5 D$ and $Q P$ m.inra-6A2, control RE714 powdery mildew resistance at the adult stage and were consistently detected in the studies of Chantret et al. (2001), Mingeot et al. (2002) and Muranty et al. (2009), involving crosses of RE714 with the susceptible lines 'Hardi' or 'Festin'. A third region involved in powdery mildew resistance at the adult stage was detected on chromosome 7A by Chantret et al. (2001) and by Muranty et al. (2009), who described two closely located QTL expressed in different years. This region had a rather minor effect (Table 1). The genetic factors involved in resistance at the seedling stage and at the adult stage on chromosome $5 \mathrm{D}$ and $6 \mathrm{~A}$ are located in the same regions. This co-localisation probably explains what was originally called the residual effect of MIRE (Chantret et al. 1999): MIRE was then a resistance gene of RE714 defined by resistance scoring at the seedling stage with specific isolates ('93-27' and '95-9') in RE714 x Hardi segregating populations, but this resistance was later broken up into the two QTL, QPms.inra-5D and QPms.inra-6A2, and MIRE was re-defined as the resistance factor located on chromosome 6A (Chantret et al. 2000). The localization and effects of these QTL are detailed in Table 1.

To assess the origin of the main genetic factors involved in RE714 powdery mildew resistance, the linked microsatellite markers obtained by Muranty et al. $(2008 ; 2009)$ were used to compare RE714 alleles to the alleles of its ancestral lines.

\section{Materials and methods}

Plant material

The pedigree of RE714 includes two interspecific crosses and several crosses with known wheat cultivars, except for the unknown genotype that pollinated the single male-sterile plant obtained from the cross Ae. tauschii no. $33 \times T$. dicoccum no. 119 had a progeny by open 
Version définitive du manuscrit publié dans / Final version of the manuscript published in :

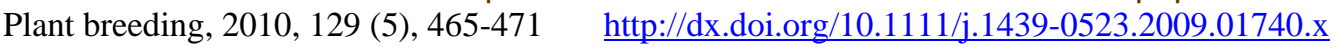

pollination (Fig. 1). The wheat lines VPM, 'Marne', 'Moisson' and 'Beauchamp', and the lines Ae. tauschii $\mathrm{n}^{\circ} 33$, Ae. ventricosa $\mathrm{n}^{\circ} 10$ and T. dicoccum $\mathrm{n}^{\circ} 119$ were used to infer the origins of the main genetic factors involved in RE714 powdery mildew resistance. Unfortunately, the $T$. persicum accession that was used to develop VPM has been lost.

Only $T$. dicoccum $\mathrm{n}^{\circ} 119$ was tested in the seedling stage resistance tests described by Muranty et al. (2008) because it was used as a differential check. T. dicoccum $n^{\circ} 119$ is resistant to specific isolates of powdery mildew at the seedling stage (isolates 'K', '93-27', '959', '95-31' and '97-23' in Muranty et al. 2008, 15 isolates in Robe and Doussinault 1995) and RE714 is also resistant to these isolates (Muranty et al. 2008, Robe and Doussinault 1995). T. dicoccum $\mathrm{n}^{\circ} 119$ was described as the donor of MlRE by Robe and Doussinault (1995). 'Beauchamp' and 'Moisson' were reported to be susceptible to 12 differential powdery mildew isolates at the seedling stage by Zeller et al. (1993) and to carry no known resistance gene. 'Marne' was susceptible to a local powdery mildew isolate in Australia and is not known to carry Pm4b (Bariana and McIntosh 1994). VPM is resistant to specific isolates of the powdery mildew pathogen at the seedling stage and carries Pm4b (Bariana and McIntosh 1993, Zeller et al. 1993). Ae. tauschii $\mathrm{n}^{\circ} 33$ was resistant to all 24 isolates tested by Robe and Doussinault (1995) at the seedling stage. VPM, 'Beauchamp', Ae. tauschii $\mathrm{n}^{\circ} 33$ and T. dicoccum $\mathrm{n}^{\circ} 119$ were tested in the adult plant resistance tests described by Muranty et al (2009). Area under disease progress curve (AUDPC) were calculated using several disease assessments as AUDPC $=\sum_{i} \mathbf{s}_{i}+x_{i 11} \mathbf{S}_{i 11}-t_{i} Z 2_{-}^{-}$where $x_{i}$ is the score at date $t_{i}$. The mean AUDPC of 'Hardi', RE714 and its tested parental lines in each test year are reported in Table 2. A multiple mean comparison test was performed with the TukeyHSD function under R (RDevelopment-Core-Team 2006) to identify significant differences between tested lines.

Microsatellite marker analysis

Genomic DNA was extracted from fresh leaves following a modified CTAB method (Doyle and Doyle 1990). The DNA concentrations were adjusted to $10 \mathrm{ng} / \mu \mathrm{l}$. PCR reactions for microsatellite markers were performed as described by Tixier et al. (1997). PCR products were separated on $6 \%$ polyacrylamide denaturing gels and visualized by silver nitrate staining or using a Li-Cor DNA analyzer (Li-Cor Inc., Lincoln, NE). For the latter system, each right primer was 5'-tailed with the M13 forward consensus sequence. The M13-tailed right primers were then used in combination with a standard M13 primer dye-labelled at the 5'-end (BoutinGanache et al. 2001). A total of 36 wheat microsatellite primer pairs were used to genotype 
Version définitive du manuscrit publié dans / Final version of the manuscript published in :

Plant breeding, 2010, 129 (5), 465-471 http://dx.doi.org/10.1111/j.1439-0523.2009.01740.x

the lines. These markers were chosen from the map of the RE714 x Hardi RIL population described in Muranty et al. (2009) to have a good representation of the support intervals (-1.5 LOD) of the main powdery mildew resistance QTL detected in this population. The data were recorded as "a band of the same size as the band of RE714" (RE), "a band of the same size as the band of 'Hardi"' (Ha), "a band with a size different from the sizes of the bands of RE714 and 'Hardi"' (D) or "no band" (NO) (Table 3).

\section{Results}

Adult plant reactions of some of the RE714 ancestral lines

Adult plant actions of VPM, 'Beauchamp', Ae. tauschii $\mathrm{n}^{\circ} 33$ and T. dicoccum $\mathrm{n}^{\circ} 119$ were evaluated together with the RE714 x Hardi RIL population (Muranty et al. 2009). Mean AUDPC for powdery mildew were generally higher in 2001 and 2002 when the tests were performed in tunnel houses which provided an environment more favourable to powdery mildew development because they were warmer and more humid (the plants were regularly watered) than the field. Three and four groups of lines similar in AUDPC means were identified with the multiple mean comparison test in 2000 and 2001, respectively (Table 2). Ae. tauschii no. 33 was highly resistant at the adult plant stage in the 3 years, and its mean AUDPC was lower than or very close to theRE714 mean AUDPC: the differences between Ae. tauschii no. 33 and RE714 were not significant $(\mathrm{P}=0.05)$. T. dicoccum $\mathrm{n}^{\circ} 119$ had a mean AUDPC very close to RE714 mean AUDPC in 2000, but was significantly more susceptible than RE714 in 2001. In 2002, it had also an intermediate response level. 'Beauchamp' had an intermediate response level in all 3 years, which resulted in a mean AUDPC below or near the mean of the recombinant inbred lines from the cross RE714 x 'Hardi'. However, 'Beauchamp' was not significantly different from RE714 in 2000 whereas it was significantly more susceptible than RE714 in 2001. 'Beauchamp' was significantly more resistant than 'Hardi' in 2000 and 2001. These results confirmed the weak adult plant resistance of 'Beauchamp' that was recorded when it was registered in (Anonymous 1979). VPM was susceptible in all 3 years and was not significantly different from 'Hardi' in 2000 and 2001. It was also not significantly different from 'Beauchamp' in 2000.

The origin of the main QTL was investigated by comparing the microsatellite marker alleles of RE714 to those of its parental lines. These markers had been mapped in a RE714 x Hardi RIL population (Muranty et al. 2009) (see Fig. 2). For each genetic factor, we focused our attention to the parental lines that could be donors of the QTL, and excluded the lines that did not possess the resistance factor carrying genome. Indeed, Ae. tauschii n $^{\circ} 33$ (DD) and $A e$ Breeding, 129 (5), 465-471. DOI : 10.1111/j.1439-0523.2009.01740.x 
Version définitive du manuscrit publié dans / Final version of the manuscript published in :

Plant breeding, 2010, 129 (5), 465-471 http://dx.doi.org/10.1111/j.1439-0523.2009.01740.x

ventricosa $\mathrm{n}^{\circ} 10\left(\mathrm{DDN}^{\mathrm{v}} \mathrm{N}^{\mathrm{v}}\right)$ as well as $T$. dicoccum $\mathrm{n}^{\circ} 119$ (AABB) cannot be the donors of genetic factors located in the $\mathrm{A}$ and $\mathrm{D}$ genomes, respectively.

Origin of $P m 4 b$, a gene mapped on chromosome $2 \mathrm{~A}$

Because 'Beauchamp', 'Marne' and 'Moisson' were recorded as susceptible to all tested powdery mildew isolates at the seedling stage, including isolates avirulent on $P m 4 b$ reference lines, they cannot be the donor of $P m 4 b$. T. dicoccum $\mathrm{n}^{\circ} 119$ is susceptible to some isolates that are avirulent on reference lines carrying $P m 4 b$ (Robe and Doussinault, 1995; Muranty et al 2008) so it can not be the donor of $P m 4 b$. This leaves only VPM and the unknown line that pollinated the single male-sterile plant obtained in the initial cross between Ae. tauschii no. 33 and T. dicoccum no. 119 as potential donor of $P m 4 b$ to RE714. The microsatellite loci located within the support interval of $Q P m s$.inra-2A3, corresponding to the $P m 4 b$ gene (Muranty et al 2008), are Xgwm311, Xgpw4474 and Xgpw4456 (Fig. 2). In the vicinity of the Pm4b gene on linkage group 2A3, RE714 had the same alleles as VPM at microsatellite loci Xcfd0251, Xgwm526 and Xgwm311, but not at the Xgwm382 and Xgpw4474 loci (Table 3). This confirmed that VPM is the most likely donor of $P m 4 b$ to RE714. Among the parental lines of VPM, the lines that contributed to the A genome are 'Marne' and the T. persicum line, which is the most likely donor of $P m 4 b$ because 'Marne' is susceptible.

\section{Origin of $Q P m$.inra-5D}

The microsatellite loci located within the support interval of QPm.inra-5D are Xcfd0008, Xgwm494-5D, Xgwm639-5D, Xgpw5207-5D, Xcfd0057 and Xcfd0026 (Fig. 2). The putative wild species donors of this resistance factor are Ae. tauschii $\mathrm{n}^{\circ} 33$ (DD) and Ae ventricosa $\mathrm{n}^{\circ} 10\left(\mathrm{DDN}^{v} \mathrm{~N}^{v}\right)$. RE714 had the same allele as Ae. tauschii $\mathrm{n}^{\circ} 33$, which is completely resistant to powdery mildew, at all six microsatellite loci located within the support interval of QPm.inra-5D, but not at other nearby loci located outside the support interval, namely Xgpw4020, Xgwm159, Xcfd0007, Xcfd0003 and Xcfd0012. On the contrary, Ae ventricosa $\mathrm{n}^{\circ} 10$ had an allele different from the RE714 allele at four of the six microsatellite loci located within the support interval of Qpm.inra-5D. Consequently, the most probable origin of QPm.inra-5D in RE714 was Ae. tauschii $\mathrm{n}^{\circ} 33$. The QTL QPm.inra-5D explained up to $66.7 \%$ of the phenotypic variance at the seedling stage and up to $56.3 \%$ at the adult plant stage (Table 1), but its additive effects (-22.1 for AUDPC in 2000, -68.6 in 2001 and -46.0 in 2002, see Table 3 in Muranty et al (2009)) are not high enough to explain the difference between Ae. tauschii $\mathrm{n}^{\circ} 33$ and the mean of the RE714 x Hardi RIL population (Table 2). Besides, the Breeding, 129 (5), 465-471. DOI : 10.1111/j.1439-0523.2009.01740.x 
Version définitive du manuscrit publié dans / Final version of the manuscript published in :

Plant breeding, 2010, 129 (5), 465-471 http://dx.doi.org/10.1111/j.1439-0523.2009.01740.x

results indicate an interstitial position of the fragment of Ae. tauschii $\mathrm{n}^{\circ} 33$ introgressed in the 5D chromosome of RE714. The length of this introgressed fragment was approximately 40 cM on the map obtained in the RE714 x Hardi RIL population (Muranty et al 2009).

\section{Origin of QPm.inra-6A2}

The microsatellite loci located within the support interval of QPm.inra-6A2 and QPms.inra$6 A 2 a$ are $X g p w 7388$ and $X D u P w 167$, whereas only one microsatellite locus, namely Xgwm427, was located within the support interval of QPms.inra- 6A2b. The putative wild species donors of resistance factors in this region are $T$. dicoccum $\mathrm{n}^{\circ} 119$ (AABB) and the lost T. persicum accession that was used to develop VPM. T. dicoccum $\mathrm{n}^{\circ} 119$ was previously suggested as the donor of the so-called MIRE resistance (Robe and Doussinault 1995). RE714 had the same allele as T. dicoccum $\mathrm{n}^{\circ} 119$ at microsatellite loci Xgwm617, Xcfa2114, Xgwm427, Xbarc104, Xgpw7388 and XDuPw167, but not at Xgwm169, whereas VPM had the same allele as RE714 at only one of these loci, namely Xbarc104. We could thus confirm that the most probable origin of QPm.inra-6A2 in RE714 was T. dicoccum $\mathrm{n}^{\circ} 119$, as already suggested by Robe and Doussinault (1995) and Chantret et al. (2000), and show that the fragment of $T$. dicoccum $n^{\circ} 119$ introgressed on the $6 \mathrm{~A}$ chromosome of RE714 has a distal position. The length of this introgressed fragment was approximately $76 \mathrm{cM}$ on the map obtained in the RE714 x Hardi RIL population (Muranty et al 2009).

\section{Origin of $Q P m . i n r a-7 A 3 a$ and $Q P m . i n r a-7 A 3 b$}

The microsatellite loci located within the support interval of QPm.inra-7A3a are Xgpw2308, Xgpw2338, Xgpw2299, Xcfa2040a and Xgwm146. This QTL could correspond to the QTL detected by Chantret et al (2001) near Xgwm344 in an $\mathrm{F}_{2: 3}$ population derived from the cross RE714 x Hardi. RE714 had the same allele as 'Beauchamp' and 'Moisson' at the microsatellite loci Xgpw2338 and Xgpw2299, and also the same as 'Moisson' at Xgwm146, but not at the other loci. 'Marne' had the same allele as RE714 at the microsatellite loci Xgpw2338 and Xgwm146 and not at the other loci but VPM had the same allele as RE714 only at the microsatellite locus $X g p w 2338$. The accession T. dicoccum $\mathrm{n}^{\circ} 119$ also had the same allele as RE714 at the microsatellite locus Xgpw2299 and Xgwm344. Consequently, it was difficult to identify the donor of QPm.inra-7A3a among the parental line of RE714 that were tested. The unknown line that pollinated the single male-sterile plant obtained in the initial cross between Ae. tauschii no. 33 and T. dicoccum no. 119 could be the donor. 
Version définitive du manuscrit publié dans / Final version of the manuscript published in :

Plant breeding, 2010, 129 (5), 465-471 $\quad$ http://dx.doi.org/10.1111/j.1439-0523.2009.01740.x

The microsatellite loci located within the support interval of QPm.inra-7A3b are Xgpw2252 and Xcfa2019. 'Beauchamp' was the only tested parental line to have the same allele as RE714 at these loci, whereas 'Moisson' had the same allele as RE714 only at Xcfa2019. 'Beauchamp' is susceptible to all powdery mildew isolates at the seedling stage, but has an intermediate response level at the adult stage (Table 2, and see above). As the QTL QPm.inra-7A3b is expressed only at the adult stage and its effect is quite weak (Table 1), 'Beauchamp' could be the origin of the favourable allele in RE714.

\section{Discussion}

Several powdery mildew resistance genes have been introduced from bread wheat related species with an AABB genome: Pm3h and Mld from T. durum, Pm4a and Pm5a from T. dicoccum, Pm4b, Pm33 and PmPs5A from T. carthlicum, and Pm16, Pm26, Pm30, Pm31, MlTd1055 and Mlzec1 from T. dicoccoides (McIntosh et al. 2008). In RE714, Pm4b probably came from $T$. persicum $=T$. carthlicum through VPM, so was introduced into bread wheat differently from the $P m 4 b$ gene in 'Armada', which has been the reference line for $P m 4 b$ in several studies (Heun and Fischbeck 1987a,b, Singrun et al. 2004). RE714 QTL on chromosome $6 \mathrm{~A}$ is another interesting gene probably introduced from one of these species, namely $T$. dicoccum. This illustrates the value of these species as genetic resources for the improvement of resistance to biotic stresses in bread wheat.

Ae. tauschii was apparently not a common source of powdery mildew resistance genes until recently. Among the named powdery mildew resistance genes, Pm2, Pm19, Pm34 and Pm35 were introduced from this species into wheat. However, $P m 2$ is widespread in cultivars grown in Europe and China (Hsam and Zeller 2002) and its origin is often more probably in old wheat varieties or landraces than in an introgression from Ae.tauschii. Within the CIMMYT wheat breeding programs, hundreds of 'synthetic' wheat lines, i.e. hybrids between species with an $\mathrm{AABB}$ genome and Ae. tauschii, have been created and their derivatives now represent a significant proportion of the parental lines used in crosses in these breeding programmes each year (Crouch et al 2009). These lines may contain additional powdery mildew resistance genes. Our results concerning common alleles in RE714 and Ae. tauschii $\mathrm{n}^{\circ} 33$ strongly suggest that the RE714 QTL on chromosome 5D originated in this accession. However, the resistance to powdery mildew conferred by this QTL is not as strong as the resistance found in Ae. tauschii n $^{\circ} 33$, either because Ae. tauschii n` 33 carries other resistance genes, or because the gene does not have the same level of expression in the hexaploid background as in the diploid. Ae. tauschii $\mathrm{n}^{\circ} 33$ was one of the parents of synthetics studied by 
Version définitive du manuscrit publié dans / Final version of the manuscript published in :

Plant breeding, 2010, 129 (5), 465-471 http://dx.doi.org/10.1111/j.1439-0523.2009.01740.x

Lutz et al. (1994) who showed that synthetic amphiploids generally express lower levels of resistance to powdery mildew than the respective diploid parental lines.

Reduced recombination is perceived as a general drawback of introgressions from related species. For example, in the vicinity of $P$ chl, a gene for eyespot resistance introduced from Ae. ventricosa into wheat through VPM, 6 markers showed complete linkage in a population of 254 RIL segregating for Pch1, whereas three of these markers spanned a $3.8 \mathrm{cM}$ segment in the ITMI population that does not segregate for Pchl (Leonard et al. 2008). On the contrary, fragments originating from Ae. tauschii $\mathrm{n}^{\circ} 33$ and $T$. dicoccum $\mathrm{n}^{\circ} 119$ around QPm.inra-5D and QPm.inra-6A2 in RE714 did not seem to have reduced recombination. Consequently, developing advanced intercross lines with RE714 could help delineate its powdery mildew resistance factors to smaller intervals and perhaps result in genotypes with reduced linkage drag.

More generally, wheat breeders should enlarge their use of related species from the primary gene pool, for example by creating and exploiting 'synthetic wheat', because genetic diversity within these species does not seem to be fully exploited and introgression of interesting genetic factors from these species does not require difficult chromosome engineering strategies. Often, the value of such genotypes for an agronomic trait will not be predictive of the value of the genotypes obtained from them in synthetic wheats or direct hybrid derivatives, as seen in the present example of powdery mildew resistance in RE714 and $A e$. tauschii $\mathrm{n}^{\circ} 33$. A strategy to introduce genetic diversity from related species of the primary gene pool into wheat would be to perform widescale advanced backcrosses, by creating intercross populations involving several synthetic wheat genotypes and modern breeding lines and then apply recurrent selection for adaptation to modern cultivation techniques and desirable agronomic traits, with mild selection pressure in order to avoid a too rapid shrinkage of genetic diversity.

\section{Acknowledgements}

Molecular mapping results were in great part obtained through the OUEST-genopole® genotyping technical platform, successively supervised by S. Prioul, A. Lostanlen and S. Coedel. We thank P. Sourdille for sharing information about microsatellite primer sequences ahead of publication. We thank J. Jahier and M. Trottet for their valuable comments on the first draft of this article. We thank the reviewers for their careful reading which helped us improve this paper. 
Version définitive du manuscrit publié dans / Final version of the manuscript published in :

Plant breeding, 2010, 129 (5), 465-471 $\quad$ http://dx.doi.org/10.1111/j.1439-0523.2009.01740.x

\section{References}

Anonymous, 1979: Bulletin des variétés. Céréales \& fiches descriptives des variétés inscrites en octobre 1978. GEVES, La Minière, France.

Bariana, H.S., and R.A. McIntosh, 1993: Cytogenetic studies in wheat. XV. Location of rust resistance genes in VPM1 and their genetic linkage with other disease resistance genes in chromosome 2A. Genome 36, 476-482.

Bariana, H.S., and R.A. McIntosh, 1994: Characterisation and origin of rust and powdery mildew resistance genes in VPM1 wheat. Euphytica 76, 53-61.

Boutin-Ganache, I., M. Raposo, M. Raymond, and C.F. Deschepper, 2001: M13-tailed primers improve the readability and usability of microsatellite analyses performed with two different allele-sizing methods. BioTechniques 31, 24-27.

Chantret, N., M.T. Pavoine, and G. Doussinault, 1999: The race-specific resistance gene to powdery mildew, MlRE, has a residual effect on adult plant resistance of winter wheat line RE714. Phytopathology 89, 533-539.

Chantret, N., P. Sourdille, M. Roder, M. Tavaud, M. Bernard, and G. Doussinault, 2000: Location and mapping of the powdery mildew resistance gene MIRE and detection of a resistance QTL by bulked segregant analysis (BSA) with microsatellites in wheat. Theor. Appl. Genet. 100, 1217-1224.

Chantret, N., D. Mingeot, P. Sourdille, M. Bernard, J.M. Jacquemin, and G. Doussinault, 2001: A major QTL for powdery mildew resistance is stable over time and at two development stages in winter wheat. Theor. Appl. Genet. 103, 962-971.

Crouch, J.H., T.S. Payne, S. Dreisigacker, H. Wu, and H.-J. Braun, 2009: Improved Discovery and Utilization of New Traits for Breeding Wheat Facts and Futures 2009, 42-51. CIMMYT, Mexico, D.F.

Doyle, J.J., and J.L. Doyle, 1990: Isolation of DNA from fresh tissue. Focus 12, 13-15.

Feuillet, C., P. Langridge, and R. Waugh, 2008: Cereal breeding takes a walk on the wild side. Trends Genet. 24, 24-32.

Heun, M., and G. Fischbeck, 1987a: Genes for powdery mildew resistance in cultivars of spring wheat. Plant Breeding 99, 282-288.

Heun, M., and G. Fischbeck, 1987b: Identification of wheat powdery mildew resistance genes by analysing host-pathogen interactions. Plant Breeding 98, 124-129.

Hospital, F., 2005: Selection in backcross programmes. Philos. Trans. R. Soc. Lond., Ser. B: Biol. Sci. 360, 1503-1511. Breeding, 129 (5), 465-471. DOI : 10.1111/j.1439-0523.2009.01740.x 
Version définitive du manuscrit publié dans / Final version of the manuscript published in :

Plant breeding, 2010, 129 (5), 465-471 $\quad$ http://dx.doi.org/10.1111/j.1439-0523.2009.01740.x

Hsam, S.L.K., and F.J. Zeller, 2002: Breeding for powdery mildew resistance in common wheat (Triticum aestivum L.), In: R. R. Bélanger, W. R. Bushnell, A. J. Dik and T. L. W. Carver, (eds.) Powdery Mildews: a Comprehensive Treatise, 219-238. Amer Phytopathological Soc, St Paul.

Jiang, J.M., B. Friebe, and B.S. Gill, 1994: Recent advances in alien gene-transfer in wheat. Euphytica 73, 199-212.

Leonard, J., C. Watson, A. Carter, J. Hansen, R. Zemetra, D. Santra, K. Campbell, and O. Riera-Lizarazu, 2008: Identification of a candidate gene for the wheat endopeptidase $E p-D 1$ locus and two other STS markers linked to the eyespot resistance gene Pch1. Theor. Appl. Genet. 116, 261-270.

Lutz, J., S.L.K. Hsam, E. Limpert, and F.J. Zeller, 1994: Powdery mildew resistance in Aegilops tauschii Coss. and synthetic hexaploid wheats. Genet. Resour. Crop Evol. 41, 151158.

McIntosh, R.A., Y. Yamazaki, J. Dubcovsky, J. Rogers, C. Morris, D.J. Somers, R. Appels, and K.M. Devos, 2008: Catalogue of Gene Symbols for Wheat.

Mingeot, D., N. Chantret, P.V. Baret, A. Dekeyser, N. Boukhatem, P. Sourdille, G. Doussinault, and J.M. Jacquemin, 2002: Mapping QTL involved in adult plant resistance to powdery mildew in the winter wheat line RE714 in two susceptible genetic backgrounds. Plant Breeding 121, 133-140.

Muranty, H., M.T. Pavoine, B. Jaudeau, W. Radek, G. Doussinault, and D. Barloy, 2008: A quantitative approach detects three QTLs involved in powdery mildew resistance at the seedling stage in the winter wheat line RE714. Aust. J. Agric. Res. 59, 714-722.

Muranty, H., M.T. Pavoine, B. Jaudeau, W. Radek, G. Doussinault, and D. Barloy, 2009: Two stable QTL involved in adult plant resistance to powdery mildew in the winter wheat line RE714 are expressed at different times along the growing season. Mol. Breed. 23, 445-461.

Qi, L.L., B. Friebe, P. Zhang, and B.S. Gill, 2007: Homoeologous recombination, chromosome engineering and crop improvement. Chromosome Res. 15, 3-19.

R-Development-Core-Team, 2006: R: A language and environment for statistical computing. R Foundation for Statistical Computing, Vienna, Austria.

Robe, P., and G. Doussinault, 1995: Genetic analysis of powdery-mildew resistance of a winter-wheat line, RE714, and identification of a new specific-resistance gene. Plant Breeding 114, 387-391. 
Version définitive du manuscrit publié dans / Final version of the manuscript published in :

Plant breeding, 2010, 129 (5), 465-471 http://dx.doi.org/10.1111/j.1439-0523.2009.01740.x

Roussel, V., J. Koenig, M. Beckert, and F. Balfourier, 2004: Molecular diversity in French bread wheat accessions related to temporal trends and breeding programmes. Theor. Appl. Genet. 108, 920-930.

Singrun, C., S.L.K. Hsam, F.J. Zeller, G. Wenzel, and V. Mohler, 2004: Localization of a novel recessive powdery mildew resistance gene from common wheat line RD30 in the terminal region of chromosome 7AL. Theor. Appl. Genet. 109, 210-214.

Tixier, M.H., P. Sourdille, M. Röder, P. Leroy, and M. Bernard, 1997: Detection of wheat microsatellites using a non radioactive silver-nitrate staining method. J. Genet. Breed. 51, $175-177$.

Trottet, M., and F. Dosba, 1983: Cytogenetical analysis and behavior towards Septoria nodorum of hybrids between Triticum sp and Aegilops squarrosa and of their progenies. Agronomie 3, 659-664.

Xie, W.L., and E. Nevo, 2008: Wild emmer: genetic resources, gene mapping and potential for wheat improvement. Euphytica 164, 603-614.

Zeller, F.J., J. Lutz, E.I. Reimlein, E. Limpert, and J. Koenig, 1993: Identification of powdery mildew resistance genes in common wheat (Triticum aestivum L). II. French cultivars. Agronomie 13, 201-207. 
Version définitive du manuscrit publié dans / Final version of the manuscript published in :
Plant breeding, 2010, 129 (5), 465-471 http://dx.doi.org/10.1111/.1439-0523.2009.01740.x

Table 1 Main genetic factors controlling RE714 powdery mildew resistance combining data at the seedling stage (15 isolates in a RIL population, three isolates in an $\mathrm{F}_{2: 3}$ population) and at the adult p pancht stage (three years in a RIL and a DH population, 2 years in an $\mathrm{F}_{2: 3}$ population)

\begin{tabular}{|c|c|c|c|c|c|c|c|c|c|}
\hline \multirow{2}{*}{\multicolumn{2}{|c|}{$\begin{array}{l}\text { Chr. } \\
\text { region QTL }\end{array}$}} & \multicolumn{3}{|c|}{ Resistance faction } & \multirow[b]{2}{*}{ QTL characteristics } & \multirow[b]{2}{*}{ Upstream flanking marker } & \multirow{2}{*}{$\begin{array}{l}\text { Peak position } \\
(\mathrm{cM})^{1}\end{array}$} & \multirow[b]{2}{*}{$R^{2} \%{ }^{2}$} & \multirow[t]{2}{*}{ Ref. } \\
\hline & & Growth stage & & opillation & & & & & \\
\hline $2 \mathrm{~A} 3$ & QPms.inra- $2 A 3$ & seedling & RIL & 吾 & 6 isolates & gpw4456 & $0.0-2.0$ & $76.0-92.9$ & Muranty et al. (2008) \\
\hline \multirow[t]{4}{*}{ 5D } & QPms.inra-5D & seedling & RIL & 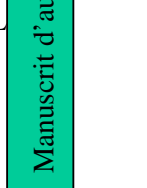 & 12 isolates & $\begin{array}{l}\text { cfd0026 (9 isolates) or } \\
\text { gpw5207-5D ( } 2 \text { isolates }) \text { or } \\
\text { gwm494-5D ( } 1 \text { isolate })\end{array}$ & $0.0-8.0$ & $10.6-66.7$ & Muranty et al. (2008) \\
\hline & \multirow[t]{3}{*}{ QPm.inra-5D } & \multirow[t]{3}{*}{ adult } & RIL & $\vec{z}$ & $\begin{array}{l}\text { AUDPC ( } 3 \text { years }) \text { and } \\
\text { individual scores } \\
\text { ( } 4 \text { or } 5 \text { each year })\end{array}$ & $\begin{array}{l}\text { cfd0026 (15 traits) or } \\
\text { gpw5207-5D (1 trait) }\end{array}$ & $0.0-2.0$ & $8.5-56.3$ & Muranty et al. (2009) \\
\hline & & & $\mathrm{DH}$ & $\sum_{\overline{0}}^{\bar{\Xi}}$ & AUDPC (3 years) & $\begin{array}{l}\text { cfd0026 (1 year) or } \\
\text { gbxG083c ( } 2 \text { years })\end{array}$ & $0.0-4.0$ & $33.5-37.9$ & Chantret et al. (2001) \\
\hline & & & $\mathrm{F}_{2: 3}$ & 吾 & AUDPC (2 years) & cfd0026 & 2.0 & $28.1-37.4$ & Chantret et al. (2001) \\
\hline \multirow[t]{6}{*}{$6 \mathrm{~A} 2$} & \multirow[t]{2}{*}{ QPms.inra-6A2a } & \multirow[t]{2}{*}{ seedling } & RIL & 三 & 2 isolates & gpw7388 & 4.0 & $19.8-30.7$ & Muranty et al. (2008) \\
\hline & & & $\mathrm{F}_{2: 3}$ & 荧 & 3 isolates & ksuD27 & - & $24.1-37.0$ & Chantret et al. (2000) \\
\hline & QPms.inra-6A2b & seedling & RIL & : & 1 isolate & gwm427 & 0.0 & 14.1 & Muranty et al. (2008) \\
\hline & \multirow[t]{3}{*}{ QPm.inra-6A2 } & \multirow[t]{3}{*}{ adult } & RIL & 产 & $\begin{array}{l}\text { AUDPC ( } 1 \text { year }) \text { and } \\
\text { individual scores } \\
\text { (1 to } 4 \text { each year) }\end{array}$ & gpw7388 & $2.0-4.0$ & 12.2 & Muranty et al. (2009) \\
\hline & & & $\mathrm{DH}$ & & AUDPC (1 year) & MIRE & - & 12.2 & Chantret et al. (2001) \\
\hline & & & $\mathrm{F}_{2: 3}$ & 总 & AUDPC (2 years) & gwm427 & $6.0-8.0$ & $8.8-13.4$ & Chantret et al. (2001) \\
\hline \multirow[t]{3}{*}{ 7A3 } & \multirow[t]{2}{*}{ QPm.inra-7A3-a } & \multirow[t]{2}{*}{ adult } & RIL & 写 & 2 individual scores in 2000 & P32M51n & 6.0 & $10.8-18.7$ & Muranty et al. (2009) \\
\hline & & & $\mathrm{F}_{2: 3}$ & $\bar{s}$ & AUDPC (1 year) & gwm344 & 4.0 & 6.4 & Chantret et al. (2001) \\
\hline & QPm.inra-7A3-b & adult & RIL & $\bar{z}$ & AUDPC in 2001 & gpw2252 & 8.0 & 5.9 & Muranty et al. (2009) \\
\hline
\end{tabular}

${ }^{1}$ Distance to the upstream flanking marker in th

${ }^{2}$ Percentage of phenotypic variance explained 


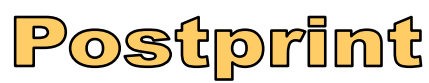

Version définitive du manuscrit publié dans / Final version of the manuscript published in :

Plant breeding, 2010, 129 (5), 465-471 http://dx.doi.org/10.1111/j.1439-0523.2009.01740.x

Table 2: Mean AUDPC for powdery mildew responses of RE714, 'Hardi', some of the parental lines of RE714 and the RIL derived from the cross RE714 x 'Hardi', in adult stage reaction tests described by Muranty et al. (2009). These tests were performed under naturally infected field conditions in Le Rheu (France), in the field in 2000 and in tunnel houses in 2001 and 2002. The 2000 and 2001 tests were sown in October in 1999 and 2000, respectively, whereas the 2002 test was sown in February 2002. ${ }^{1}$

\begin{tabular}{llllllll}
\hline Year & RE714 & Hardi & Ae. tau $\mathrm{n}^{\circ} 33$ & T. dic $\mathrm{n}^{\circ} 119$ & Beauchamp & VPM & RIL \\
\hline 2000 & $84.5 \mathrm{a}$ & $238.5 \mathrm{c}$ & $87.5 \mathrm{a}$ & $87.5 \mathrm{a}$ & $116.7 \mathrm{ab}$ & $184.5 \mathrm{bc}$ & 149 \\
2001 & $325 \mathrm{ab}$ & $668 \mathrm{~d}$ & $280 \mathrm{a}$ & $481 \mathrm{c}$ & $438 \mathrm{bc}$ & $601 \mathrm{~d}$ & 463 \\
$2002^{2}$ & 170 & 543 & 58 & 254 & 320 & 400 & 312 \\
\hline
\end{tabular}

${ }^{1}$ Mean AUDPC followed by different letters are significantly different.

${ }^{2}$ Statistical assessment of mean differences could not be performed with the 2002 data. 


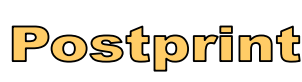

Version définitive du manuscrit publié dans / Final version of the manuscript published in :

cfa2040a

gwm146

\section{RE}

RE Ha $\quad$ D

D

Loci located within support intervals

${ }^{1}$ Genotypes were scored with reference the genotypes of RE714 and 'Hardi'

RE, a band of the same size as the band of RE714; Ha, a band of the same size as the band of 'Hardi'; RE?, Ha?, a band of the same size as the band of RE714, or 'Hardi', but much fainter or much st when the marker is codominant in $\mathrm{R}$ ( 4 x 'Hardi'.

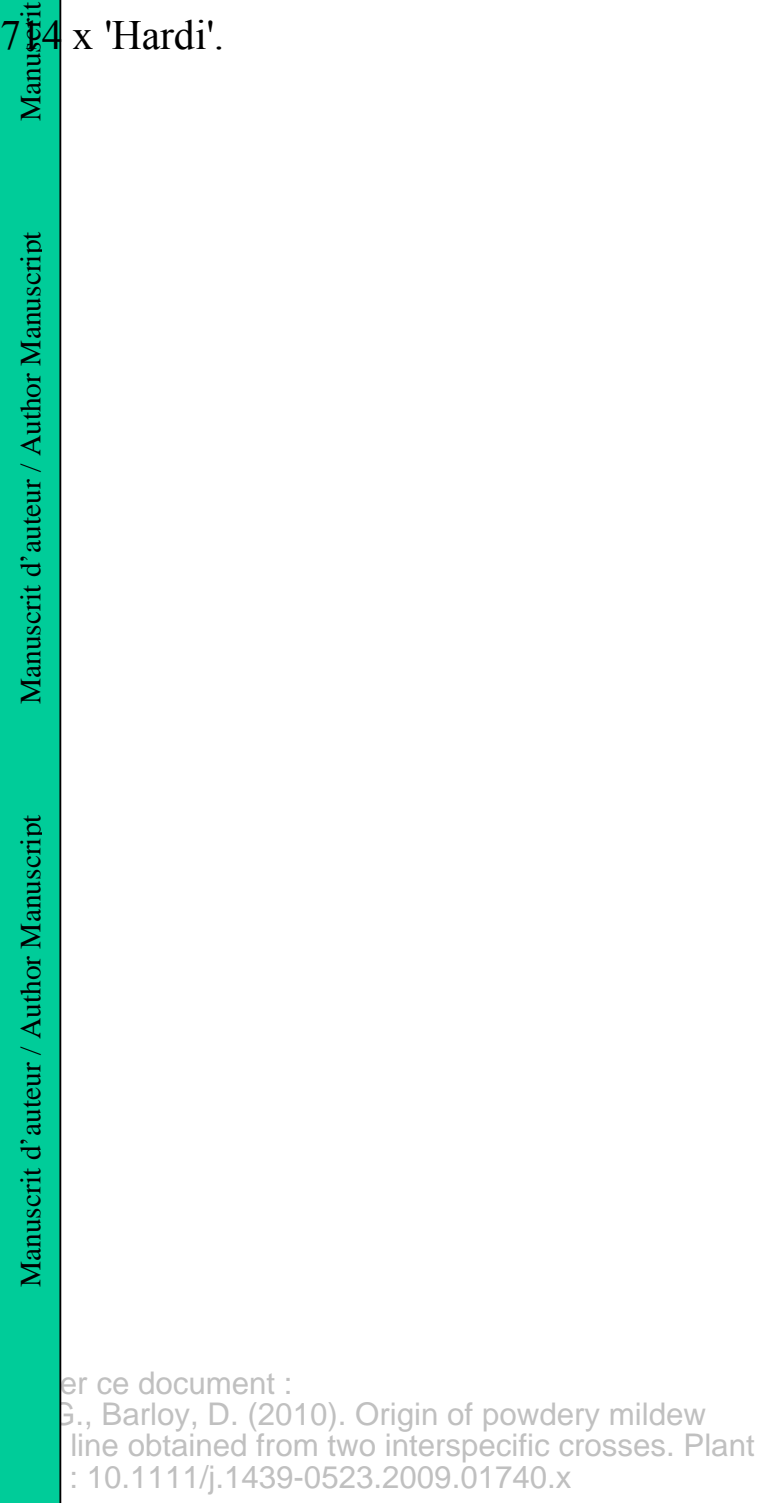


Version définitive du manuscrit publié dans / Final version of the manuscript published in :

Plant breeding, 2010, 129 (5), 465-471 http://dx.doi.org/10.1111/j.1439-0523.2009.01740.x

\section{Figure legend}

Fig. 1 Pedigree of the winter wheat line RE714

Fig. 2 Framework genetic maps of groups 2A3, 5D, 6A2 and 7A3 obtained in the wheat RE714 x Hardi RIL population ((Muranty et al. 2009)). Probable positions of other loci are indicated on the right. The position of the QTL detected for powdery mildew resistance are indicated at right, with a horizontal line representing the peak of each QTL and a vertical line representing the confidence interval of each QTL. Markers for which RE714 had the same allele as VPM on linkage group 2A3 are in red, those for which RE714 had the same allele as Ae. tauschii $\mathrm{n}^{\circ} 33$ on linkage group 5D are in green, those for which RE714 had the same allele as $T$. dicoccum $\mathrm{n}^{\circ} 119$ on linkage group 6A2 are in blue and those for which RE714 had the same allele as Beauchamp on linkage group 7A3 are in orange. The markers for which RE714 had the same allele as $T$. dicoccum $\mathrm{n}^{\circ} 119$ on linkage group7A3 are in blue italics. 


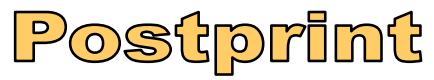

Version définitive du manuscrit publié dans / Final version of the manuscript published in :

Plant breeding, 2010, 129 (5), 465-471 http://dx.doi.org/10.1111/j.1439-0523.2009.01740.x

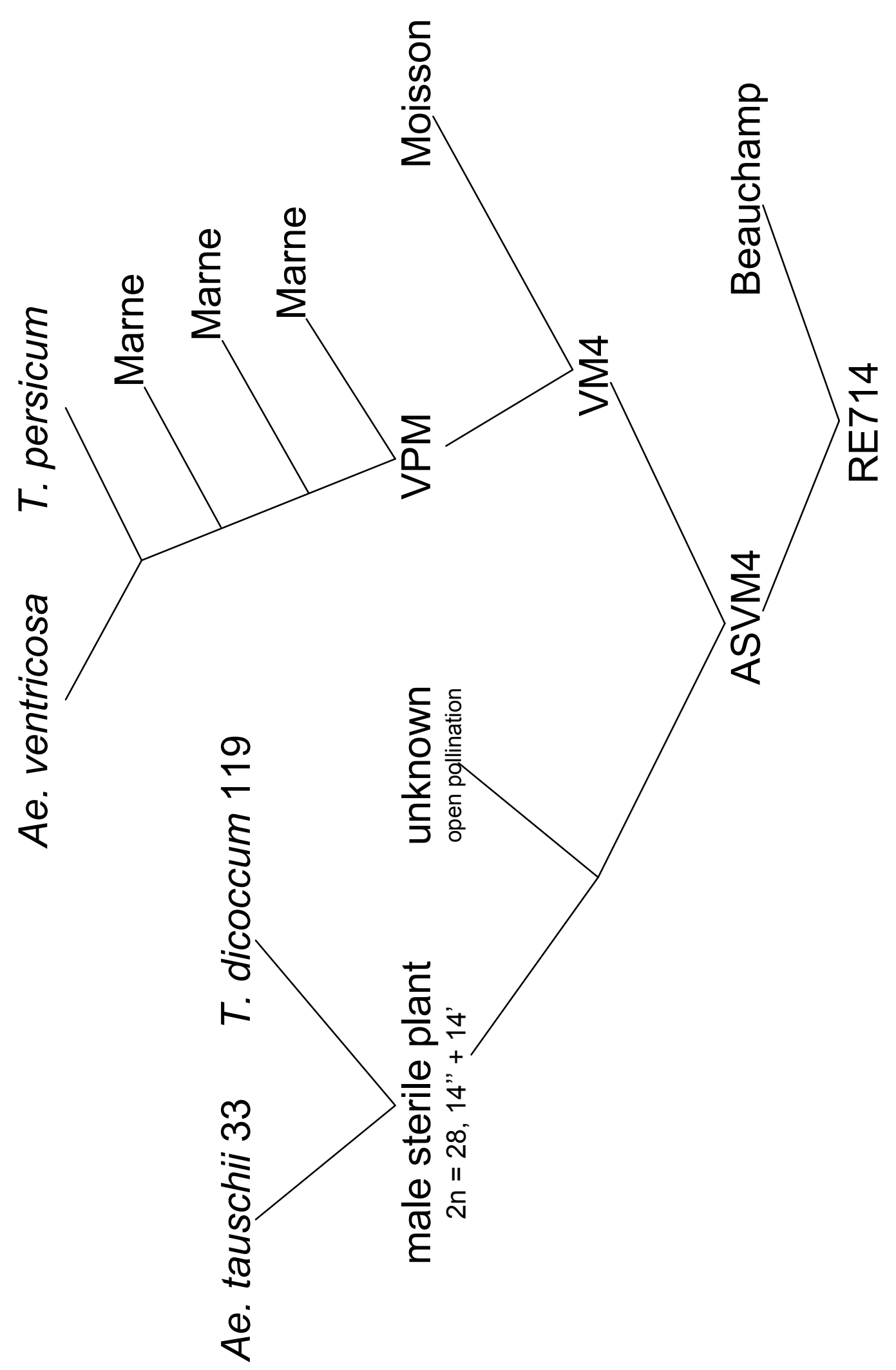




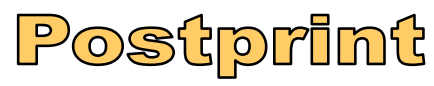
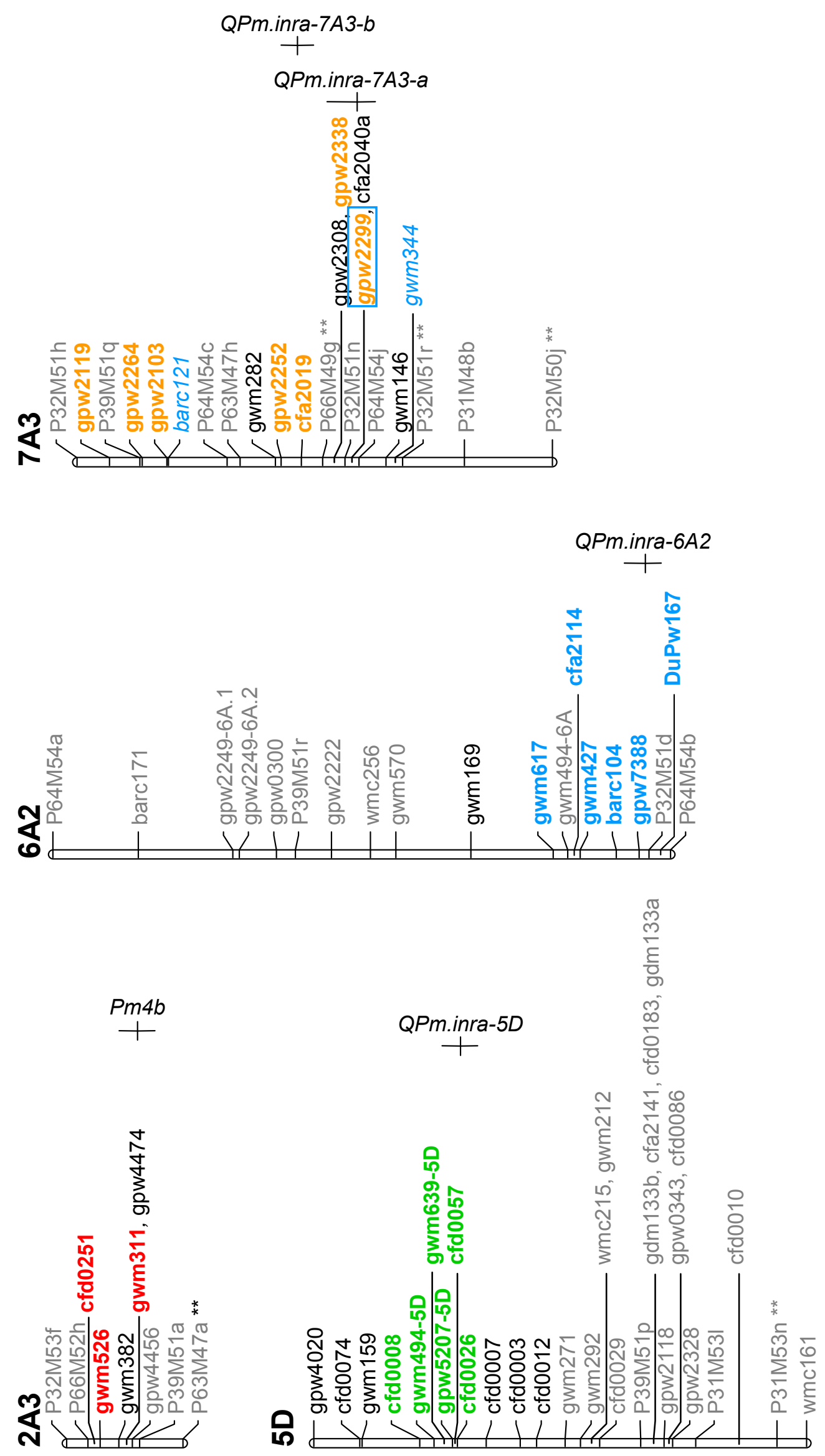

$\sum_{0}$
0
0 